Original Article (short paper)

\title{
Physical activity and food habits are associated with television time on weekends in Brazilian workers
}

\author{
Marina Christofoletti $^{1}$ (D), Giovani Firpo Del Duca ${ }^{1}$ (D), Aline Mendes Gerage ${ }^{1}$ (D), Lisandra Maria Konrad ${ }^{1}$ (D), \\ Elusa Santina Antunes de Oliveira ${ }^{2}$ (D), Mauro Virgílio Gomes de Barros $^{3}$ (D), Markus Vinicius Nahas $^{1}$ (D)
${ }^{1}$ Universidade Federal de Santa Catarina, UFSC, Department of Physical Education, Florianopolis, SC, Brazil; ${ }^{2}$ Instituto Federal de Santa Catarina, IFSC, Palhoça, SC, Brazil; ${ }^{3}$ Universidade de Pernambuco, UPE, College of Physical Education, Recife, PE, Brazil

\begin{abstract}
Aims: Investigated the relation between eating habits or physical activity and weekend television viewing time, regardless of weekday television viewing in Brazilian workers. Methods: A representative cross-sectional study was conducted to measure the relation between weekend television viewing time and dietary indicators and physical activity across different domains in 47,477 workers. A questionnaire measured the time spent watching television per day on the weekend, physical activity indicators across different domains and eating habits. Absolute and relative frequencies and multinomial logistic regression adjusted were used to describe and identify the relationship between time spent watching television on the weekend and physical activity indicators or eating habits. Results: Workers who were physically active in the household $(\mathrm{OR}=1.09[95 \% \mathrm{CI}=1.04 ; 1.15]$ and $\mathrm{OR}=1.11[95 \% \mathrm{CI}=1.06 ; 1.16])$ and leisure-time domains $(\mathrm{OR}=1.28[95 \% \mathrm{CI}=1.22 ; 1.35]$ and $\mathrm{OR}=1.30[95 \% \mathrm{CI}=1.24 ; 1.36])$ were more likely to watch television $\geq 2$ and $\geq 4$ hours on a weekend day, respectively, than those watching television $\leq 1$ hour/day. Consuming sweets $(\mathrm{OR}=1.30[95 \% \mathrm{CI}=1.22 ; 1.39])$ and soft drinks $(\mathrm{OR}=1.11[95 \% \mathrm{CI}=1.03 ; 1.19])$ was related to television watching $\geq 4$ hours on a weekend day. However, workers who consumed fruits $(\mathrm{OR}=0.81[95 \% \mathrm{CI}=0.76 ; 0.85])$ and vegetables $(\mathrm{OR}=0.91[95 \% \mathrm{CI}=0.86 ; 0.96])$ daily were less likely to spend $\geq 4$ hours watching television on a weekend day. Conclusion: We conclude that increased television viewing time on weekends, regardless of weekday television time, is related to leisure-time and household physical activity and with unhealthy eating habits in workers. Interventions focusing on the leisure-time may be an important alternative for health promotion in workplaces.
\end{abstract}

Keywords: sedentary behavior. motor activity. food habits. occupational health. cross-sectional studies.

\section{Introduction}

Sedentary behavior is considered an important health risk factor, which increases the cardiometabolic risk even in early age, irrespective of the level of physical activity. ${ }^{1,2}$ Among the different types of sedentary behavior, epidemiological studies which specifically investigated the time spent watching television in adults have shown an association between this behavior and the occurrence of more worrisome outcomes such as an increased risk of cardiovascular diseases ${ }^{2}$ and mortality due to these diseases and all causes. ${ }^{3}$ The combination of this behavior with other unhealthy habits, such as physical inactivity and poor food habits, potentiates the negative health effects, ${ }^{4}$ leading the development of chronic non-communicable diseases. ${ }^{4-6}$

Since the time spent in sedentary behaviors is observed by the set of all activities performed in contexts of leisure-time, work, and transport, ${ }^{7}$ their deleterious health effects can be aggravated by restricted periods in the week, such as the weekend. During the weekend, the activities chosen in the leisure-time can be characterized by distraction, like television viewing, that has low use of attention, reasoning and energy expenditure. ${ }^{8}$ In addition, the sedentary behavior is the major factor associated with quality of food intake in adults ${ }^{9}$ usually with energy-dense options like sweets, chips, fast food and products with a low nutritional value and little vitamins, ${ }^{9,10}$ reflecting on weight gain and obesity in all age groups, even in adults. ${ }^{10}$

However, it should be noted that the studies cited above, which used television viewing time as an indicator of sedentary behavior, have focused on the time spent throughout the week, while there is a lack of knowledge about the implications of the time spent in this activity exclusively on weekends. Since the work activities of adults during the week generally account for more than half of their waking time, ${ }^{11}$ associated with the prolonged time spent commuting from work to household and vice-versa, ${ }^{12}$ proposing alternatives to reduce sedentary behaviors during leisure-time on weekdays may be difficult. This could be confirmed by the identification of a lack of time as one of the main barriers to leisure-time physical activity. ${ }^{13}$

It is also necessary to determine whether the sedentary behavior adopted on the weekend, a period characterized by longer leisure-time for most of the adult population, is also associated with other behaviors. Furthermore, strategies designed to reduce this behavior, specifically during this period, could have health benefits and are more easily implemented by workers 
with high workloads, considering that the works' health entails significant public expenditures in developing countries. ${ }^{14}$ Therefore, the hypothesis of the study is that weekend sedentary behavior may be related with (un)healthy habits at weekdays in workers, supporting the objective of this study, which was to investigate the relation between physical activity indicators or eating habits and television time on weekends, regardless of weekday television time, in Brazilian workers.

\section{Methods}

This study is part of a national cross-sectional survey entitled "Lifestyle and leisure-time habits of industry workers". Data were collected from industry workers of 24 out of the 27 federative units of Brazil between 2006 and 2008. The states of Rio de Janeiro, Sergipe and Piauí were not included since they did not complete the data collection in a timely manner.

The sample size was calculated independently for each federative unit using the following parameters and estimates: a prevalence of leisure-time physical inactivity of $45 \%$ (obtained from an earlier study involving industrial workers $)^{15}$, a sampling error of three percentage points, and a 95\% confidence interval; $50 \%$ was added for the design effect and an additional $20 \%$ for possible losses and refusals. The sampling process was conducted in two stages according to the size of the companies and the number of workers. In the first stage, each federal unit had an independent process, with companies were selected in a random and proportional manner considering the distribution of workers in large ( $\geq 500$ workers), medium (100 to 499 ) and small (20 to 99) companies. In the second stage, workers of all function in the companies were selected proportionally with the size of the company and according to a systematic selection strategy. This strategy counted with an alphabetical listing of all workers in each industry, having the first worker randomly selected and, consequently from a "leap" value, all other participants defined.

A previously validated questionnaire (with validity, reproducibility, and applicability) was used for data collection $^{16}$ with an update ${ }^{17}$. A team of evaluators received training, including information about the standardization of data collection, and each evaluator was responsible for the application of the instrument to groups of 3 to 15 workers. Each worker individually answered the questionnaire. The outcome of the study was television viewing time on a weekend, which was evaluated by the following question: "How many hours (on average) do you watch television on a weekend day?". For the purpose of analysis, television viewing time was categorized into $\leq 1,2$ to 3 , and $\geq 4$ hours/day as suggested in previous studies. . $^{18,19}$

The exposure variables of the study included physical activity indicators and eating habits. Physical activity was evaluated in different domains. Leisure-time physical activity was defined as a positive response to the following question: "Do you regularly perform some kind of physical activity in your leisure time, such as physical exercise (gymnastics, walking, running), sports, dance, or martial arts?" Physical activity in commuting was assessed with the question: "How do you get to work from your home on most days of the week?" The response options were walking, cycling, riding the bus, and taking a car/ motorcycle. Individuals who went to work walking or cycling were considered physically active in this domain. Physical activity at work was determined by the question "How would you describe your activities at work?" The response options were: "I spend most of the time sitting and, at most, walk short distances"; "I perform moderate activities, such as walking fast or performing manual tasks, for most of the day"; "I frequently perform vigorous physical activities." Subjects who selected the second or third option were classified as physically active at work. Physical activity in the household domain was defined as a positive response to the question "Do you usually perform vigorous housework (e.g., washing windows, cleaning the floor, washing clothes, cleaning the house, or gardening)?". Eating habits were accessed by the consumption of sweets, soft drinks and snacks with the question "How many days in a normal week do you eat ...?", categorized in none consumption or with the reporting of one weekly consumption ( $\geq 1$ day/week), even if this consumption was 1 serving/day or 1 serving/week. Additionally, the daily consumption of fruits or natural fruit juice and vegetables were evaluated. These eating habits were classified taking into consideration the recommendations of the Dietary Guidelines for the Brazilian Population.

The data were digitized by an optical reading of the questionnaires using the Sphynx program (Sphynx Software Solutions, Inc., Washington, USA). During this phase, possible inconsistencies were reviewed manually for the correction of errors.

Data were analyzed by the Stata 13.0 software, Standard Edition (Stata Corporation, College Station, USA). Absolute (n) and relative frequencies $(\%)$ were used as descriptive statistical measures. Multinomial logistic regression in crude analysis and adjusted for sociodemographic factors (gender, age, marital status, and education level) and television viewing time on weekdays was used. The results are expressed as odds ratios (OR) and their respective $95 \%$ confidence intervals $(95 \% \mathrm{CI})$. Results with a p-value $\leq 0.05$ were considered statistically significant.

The study was approved by the Ethics Committee of the Federal University of Santa Catarina (Protocols 306/2005 and 009/2007) and the Industry Social Service authorized the study.

\section{Results}

Among the 52,774 workers eligible for the study, the response rate was $90.7 \%(n=47,886)$. We chose to exclude 409 subjects who did not respond regarding their gender. Thus, the final sample consisted of 47,477 workers. Most of the participants were males $(69.8 \%)$, lived with somebody $(56.3 \%)$, and had at least nine years of schooling $(51.0 \%)$. The age category " $\leq 29$ years" was the most frequent among the participants (46.1\%).

Table 1 shows the physical activity indicators and the eating habits of industry workers. Most subjects reported to perform physical activity in the household (62.5\%), in leisure-time $(54.5 \%)$ and at work (64.7\%), but not for commuting $(72.8 \%)$. The most prevalent eating habits were the consumption of sweets $(82.6 \%)$, 
soft drinks (87.4\%) and snacks (66.7\%) at least once a week, and the lack of daily consumption of fruits (76.1\%) and vegetables $(70.1 \%)$.

The prevalence of watching television on weekend for $\leq 1,2$ to 3 , and $\geq 4$ hours/day was $32.4 \%$ (95\%CI: $32.0 ; 32.9), 29.8 \%$ (95\%CI: 29.3 ; 30.2) and 37.8\% (95\%CI: 37.4; 38.2), respectively.

After adjusting for sociodemographic factors and television viewing time on weekdays, it was observed that workers performing physical activity in the household $(\mathrm{OR}=1.09$ $[95 \% \mathrm{CI}=1.04 ; 1.15]$ and $\mathrm{OR}=1.11[95 \% \mathrm{CI}=1.06 ; 1.16])$ and in leisure-time $(\mathrm{OR}=1.28[95 \% \mathrm{CI}=1.22 ; 1.35]$ and
$\mathrm{OR}=1.30[95 \% \mathrm{CI}=1.24 ; 1.36])$ were more likely to watch television for $\geq 2$ and $\geq 4$ hours/day, respectively, than those who watched television for $\leq 1$ hour/day on weekend (Table 2). Subjects who consumed sweets $(\mathrm{OR}=1.30$; CI95\%: 1.22; 1.39) and soft drinks $(\mathrm{OR}=1.11 ; 95 \% \mathrm{CI}: 1.03 ; 1.19)$ were more likely to watch television for $\geq 4$ hours/day (Table 3 ) on weekend. On the other hand, workers who consumed fruits $(\mathrm{OR}=0.81 ; 95 \% \mathrm{CI}: 0.76 ; 0.85)$ and vegetables $(\mathrm{OR}=0.91$; $95 \% \mathrm{CI}: 0.86 ; 0.96)$ daily were less likely to spend $\geq 4$ hours/ day watching television on weekend (Table 3).

Table 1. Physical activity indicators and eating habits in industry workers. Brazil, 2006-2008 $(n=47,477)$.

\begin{tabular}{|c|c|c|c|}
\hline Variable & n & $\%$ & $\%$ Missing \\
\hline Television viewing on weekends (hours/day) & & & 0.7 \\
\hline$\leq 1$ & 15,297 & 32.4 & \\
\hline $2-3$ & 14,030 & 29.8 & \\
\hline$\geq 4$ & 17,820 & 37.8 & \\
\hline Television viewing on weekdays (hours/day) & & & 0.8 \\
\hline$\leq 1$ & 6,976 & 14.8 & \\
\hline $2-3$ & 26,900 & 57.1 & \\
\hline$\geq 4$ & 13,245 & 28.1 & \\
\hline Physical activity for commuting ( $\geq 1$ day/week) & & & 0.4 \\
\hline No & 34,436 & 72.8 & \\
\hline Yes & 12,852 & 27.2 & \\
\hline Physical activity in the household ( $\geq 1$ day/week) & & & 5.8 \\
\hline No & 16,791 & 37.5 & \\
\hline Yes & 27,941 & 62.5 & \\
\hline Physical activity in leisure-time ( $\geq 1$ day/week) & & & 0.7 \\
\hline No & 21,392 & 45.4 & \\
\hline Yes & 25,740 & 54.6 & \\
\hline Physical activity at work ( $\geq 1$ day/week) & & & 0.6 \\
\hline No & 16,660 & 35.3 & \\
\hline Yes & 30,542 & 64.7 & \\
\hline Consumption of sweets ( $\geq 1$ day/week) & & & 0.5 \\
\hline No & 8,234 & 17.4 & \\
\hline Yes & 39,009 & 82.6 & \\
\hline Consumption of soft drinks ( $\geq 1$ day/week) & & & 0.5 \\
\hline No & 5,974 & 12.6 & \\
\hline Yes & 41,286 & 87.4 & \\
\hline Consumption of snacks ( $\geq 1$ day/week) & & & 0.5 \\
\hline No & 15,620 & 33.1 & \\
\hline Yes & 31,627 & 66.9 & \\
\hline Daily consumption of fruits & & & 0.5 \\
\hline No & 35,972 & 76.1 & \\
\hline Yes & 11,271 & 23.9 & \\
\hline Daily consumption of vegetables & & & 0.4 \\
\hline No & 33,157 & 70.1 & \\
\hline Yes & 14,120 & 29.9 & \\
\hline
\end{tabular}


Table 2. Crude and adjusted relation of physical activity indicators with weekend television viewing time in industry workers. Brazil, 2006-2008

\begin{tabular}{|c|c|c|c|c|c|c|c|c|}
\hline \multirow{3}{*}{ Variable } & \multicolumn{4}{|c|}{2 to 3 hours versus $\leq 1$ hour } & \multicolumn{4}{|c|}{$\geq 4$ hours versus $\leq 1$ hour } \\
\hline & \multicolumn{2}{|c|}{ Crude analysis } & \multicolumn{2}{|c|}{ Adjusted analysis } & \multicolumn{2}{|c|}{ Crude analysis } & \multicolumn{2}{|c|}{ Adjusted analysis } \\
\hline & OR $(95 \% C I)$ & $p$ & OR $(95 \% C I)$ & $p$ & OR $(95 \% C I)$ & $p$ & OR $(95 \% C I)$ & $p$ \\
\hline $\begin{array}{l}\text { Physical activity for } \\
\text { commuting ( } \geq 1 \text { day/week) }\end{array}$ & & $<0.001^{\mathrm{a}}$ & & $0.055^{\mathrm{a}}$ & & $<0.001^{\mathrm{a}}$ & & $0.230^{\mathrm{a}}$ \\
\hline No & 1.00 & & 1.00 & & 1.00 & & 1.00 & \\
\hline Yes & $0.91(0.87 ; 0.96)$ & & $0.98(0.93 ; 1.04)$ & & $0.88(0.84 ; 0.93)$ & & $0.97(0.92 ; 1.02)$ & \\
\hline $\begin{array}{l}\text { Physical activity in the } \\
\text { household ( } \geq 1 \text { day/week) }\end{array}$ & & $0.048^{\mathrm{a}}$ & & $0.001^{\mathrm{a}}$ & & $0.003^{\mathrm{a}}$ & & $<0.001^{\mathrm{a}}$ \\
\hline No & 1.00 & & 1.00 & & 1.00 & & 1.00 & \\
\hline Yes & $1.05(1.00 ; 1.02)$ & & $1.09(1.04 ; 1.15)$ & & $1.07(1.02 ; 1.12)$ & & $1.11(1.06 ; 1.16)$ & \\
\hline $\begin{array}{l}\text { Physical activity in leisure- } \\
\text { time ( } \geq 1 \text { day/week) }\end{array}$ & & $<0.001^{\mathrm{a}}$ & & $<0.001^{\mathrm{a}}$ & & $<0.001^{\mathrm{a}}$ & & $<0.001^{\mathrm{a}}$ \\
\hline No & 1.00 & & 1.00 & & 1.00 & & 1.00 & \\
\hline Yes & $1.13(1.08 ; 1.18)$ & & $1.28(1.22 ; 1.35)$ & & $1.30(1.25 ; 1.36)$ & & $1.30(1.24 ; 1.36)$ & \\
\hline $\begin{array}{l}\text { Physical activity at work } \\
\text { ( } \geq 1 \text { day/week) }\end{array}$ & & $<0.001^{\mathrm{a}}$ & & $0.973^{\mathrm{a}}$ & & $<0.001^{\mathrm{a}}$ & & $0.456^{\mathrm{a}}$ \\
\hline No & 1.00 & & 1.00 & & 1.00 & & 1.00 & \\
\hline Yes & $0.91(0.87 ; 0.96)$ & & $1.00(0.94 ; 1.06)$ & & $0.88(0.84 ; 0.93)$ & & $0.98(0.93 ; 1.03)$ & \\
\hline
\end{tabular}

Table 3. Crude and adjusted relation of eating habits with weekend television viewing time in industry workers. Brazil, 2006-2008

\begin{tabular}{|c|c|c|c|c|c|c|c|c|}
\hline \multirow{3}{*}{ Variable } & \multicolumn{4}{|c|}{2 to 3 hours versus $\leq 1$ hour } & \multicolumn{4}{|c|}{$\geq 4$ hours versus $\leq 1$ hour } \\
\hline & \multicolumn{2}{|c|}{ Crude analysis } & \multicolumn{2}{|c|}{ Adjusted analysis } & \multicolumn{2}{|c|}{ Crude analysis } & \multicolumn{2}{|c|}{ Adjusted analysis } \\
\hline & OR $(95 \% C I)$ & $p$ & OR (95\%CI) & $p$ & OR $(95 \% C I)$ & $p$ & OR $(95 \% C I)$ & $p$ \\
\hline $\begin{array}{l}\text { Consumptions of } \\
\text { sweets ( } \geq 1 \text { day/week) }\end{array}$ & & $0.225^{\mathrm{a}}$ & & $0.279^{\mathrm{a}}$ & & $<0.001^{\mathrm{a}}$ & & $<0.001^{\mathrm{a}}$ \\
\hline No & 1.00 & & 1.00 & & 1.00 & & 1.00 & \\
\hline Yes & $0.97(0.91 ; 1.02)$ & & $1.04(0.97 ; 1.11)$ & & $1.39(1.31 ; 1.47)$ & & $1.30(1.22 ; 1.39)$ & \\
\hline $\begin{array}{l}\text { Consumptions of soft } \\
\text { drinks ( } \geq 1 \text { day/week) }\end{array}$ & & $<0.001^{\mathrm{a}}$ & & $0.865^{\mathrm{a}}$ & & $0.001^{\mathrm{a}}$ & & $0.008^{\mathrm{a}}$ \\
\hline No & 1.00 & & 1.00 & & 1.00 & & 1.00 & \\
\hline Yes & $0.81(0.76 ; 0.86)$ & & $0.99(0.92 ; 1.07)$ & & $1.12(1.05 ; 1.20)$ & & $1.11(1.03 ; 1.19)$ & \\
\hline $\begin{array}{l}\text { Consumption of } \\
\text { snacks }(\geq 1 \text { day/week) }\end{array}$ & & $<0.001^{\mathrm{a}}$ & & $0.736^{\mathrm{a}}$ & & $<0.001^{\mathrm{a}}$ & & $0.010^{\mathrm{a}}$ \\
\hline No & 1.00 & & 1.00 & & 1.00 & & 1.00 & \\
\hline Yes & $0.83(0.79 ; 0.87)$ & & $0.99(0.93 ; 1.05)$ & & $1.12(1.07 ; 1.17)$ & & $1.07(1.02 ; 1.13)$ & \\
\hline $\begin{array}{l}\text { Daily consumption of } \\
\text { fruits }\end{array}$ & & $0.002^{\mathrm{a}}$ & & $0.660^{\mathrm{a}}$ & & $<0.001^{\mathrm{a}}$ & & $<0.001^{\mathrm{a}}$ \\
\hline No & 1.00 & & 1.00 & & 1.00 & & 1.00 & \\
\hline Yes & $1.09(1.03 ; 1.15)$ & & $0.99(0.93 ; 1.05)$ & & $0.80(0.76 ; 0.85)$ & & $0.81(0.76 ; 0.85)$ & \\
\hline $\begin{array}{l}\text { Daily consumption of } \\
\text { vegetables }\end{array}$ & & $<0.001^{\mathrm{a}}$ & & $0.218^{\mathrm{a}}$ & & $<0.001^{\mathrm{a}}$ & & $0.001^{\mathrm{a}}$ \\
\hline No & 1.00 & & 1.00 & & 1.00 & & 1.00 & \\
\hline Yes & $1.10(1.04 ; 1.15)$ & & $0.96(0.91 ; 1.02)$ & & $0.88(0.84 ; 0.92)$ & & $0.91(0.86 ; 0.96)$ & \\
\hline
\end{tabular}

$\mathrm{OR}=$ odds ratio $; 95 \% \mathrm{CI}=95 \%$ confidence interval; $p=$ significance.

${ }^{\text {a }}$ Heterogeneity.

Adjusted for TV viewing time on weekdays, gender, age, and marital status, education level, physical activity in different domains, and food habits. 


\section{Discussion}

The present study investigated the relation of physical activity indicators and eating habits with television viewing time on a weekend, regardless of weekday television viewing, in adult workers. The main findings of this research indicated that physical activity in the household and in leisure-time, beyond the consumption of sweets and soft drinks were positively associated with weekend television viewing time in adult workers. In contrast, the daily consumption of fruits and vegetables was inversely associated with this outcome.

Physical activity has been shown to coexist with the adoption of sedentary behaviors. Studies indicate that, even in individuals who achieve the recommended levels of physical activity, the frequency of cardiovascular events ${ }^{2}$ and mortality ${ }^{20}$ is higher among those who report long periods in sedentary behaviors. In the worker population studied by Owen, Sugiyama, Eakin, Gardiner ${ }^{22}$ interventions in the occupational environment to encourage physical activity had the results expected with an increase in habitual practice. However, this success was not proportional to the time spent in sedentary behaviors, suggesting that interventions aimed at reducing workplace sitting time should include specific measures for this manner, reflecting or not levels of physical activity.22

The physical activity domains that were associated with more than 2 hours of television viewing are domains outside the occupational environment (household and leisure-time). Activities performed in the leisure-time of workers allow greater flexibility and diversity, with simultaneous exposure to physical activities and sedentary behaviors, such as walking at a controlled intensity and television viewing. ${ }^{23}$

Workers who were physically active in the household were more likely to watch television for 2 to 3 hours on the weekend. This result differs from a study involving the adult Thai population, which found no relationship between physical activity in this domain and television viewing time during the week..$^{24}$ Both studies were motivated by the current epidemiological scenario characterized by an increase in chronic non-communicable diseases as a result of the adoption of risk behaviors. However, the difference found in the results may be related to the occupation of the samples investigated. The present study involved industry workers, a sample different from the study of Banks, Lim, Seubsman, Bain, Sleigh ${ }^{24}$ which, although including a similar age range, showed the behavioral influence of the academic context. Furthermore, our study analyzed television viewing time on weekends and the other study the time spent watching television during the entire week, a fact that deserves attention when comparing and interpreting the findings.

Concerning to leisure-time physical activity, our study identified a positive relationship with weekend television viewing time. Assuming that these behaviors are opposing, this result raises the hypothesis that structured activities of shorter duration and higher intensity exist in leisure-time frequently in workers. Exercises are physical activities with characteristics performed outside the work environment, a fact supporting the aforementioned possibility of the simultaneous adoption of sedentary behaviors and physical activity by an individual on the same day. ${ }^{25}$ This unexpected result can be explained by the intensity of physical activity usually practice in leisuretime (moderate to vigorous-intensity), that seems to present a lower correlation with the increment of television viewing. ${ }^{16}$ Additionally, the higher prevalence of the practice of physical activity at work in the present sample could help to explain this result. Considering that individuals who were more sedentary at work were also more sedentary outside work ${ }^{26}$ the opposite may be true, that is the most physically active at work could be most active on leisure-time during the week and may compensate this with higher hours of television view during weekends.

The relationship between these behaviors should not be encouraged considering the reduction of the time spent in physical activities over time with increasing television viewing hours in adult populations. ${ }^{18}$ This is mainly observed in the case of light physical activities that interfere with habits throughout the day and, consequently, with health indicators. ${ }^{27}$

Analysis of movement patterns and activities' intensity shows that adult populations spend most of their day in light activities and sedentary behaviors; the amount of time spent in sitting or lying down position can account for up to $55 \%$ of the day. ${ }^{9}$ Sedentary behavior has also shown a strong inverse correlation with light activities, while weak correlations are observed with the time spent in moderate to vigorous physical activities. ${ }^{28}$ Thus, the encouragement of moderate to vigorous physical activities may have little influence on reducing the time spent in sedentary behaviors.

Regarding food consumption, the findings corroborate the results of previous studies, indicating that the time spent in sedentary activities, particularly television viewing, is associated with an inadequate diet. ${ }^{29}$ This can be explained by the fact that adults with an unhealthy lifestyle tend to have other unhealthy habits simultaneously. In this respect, an inadequate diet is commonly present in the most prevalent combinations of behavioral risk factors. ${ }^{30}$ The interaction between the lack of leisure-time physical activity and unhealthy eating habits has been demonstrated in the same population in a previous study, ${ }^{31}$ as well as in adult in general ${ }^{32}$ and elderly populations. ${ }^{33}$

Furthermore, evidence indicates that the higher the television viewing time, the greater the exposure of children to advertisements of easy-to-prepare and high-calorie foods, ${ }^{34}$ which possibly extends into adulthood in which the choice for unhealthy foods could be stimulated. These findings may help understand the positive relation of television viewing time with body mass index or the occurrence of cardiovascular and metabolic diseases reported by other authors, ${ }^{2}$ highlighting the importance of creating strategies that favor a reduction in weekend television viewing time, regardless of weekday time.

The results should be taken with caution due to study limitations. The fact of not carrying out random effect in analysis, taking into account the complex sampling defined in two stages (size of industry and company), may have reflected an imprecision, even if small, in the showed estimates. Furthermore, the evaluation of physical activity in the different domains did not permit to obtain information about the duration and intensity of physical activity. There was also no information about weekly working hours of the subjects or working on weekends, which could interfere in the results and should be considered in futures studies. On the other hand, to the 
best of our knowledge, there are no studies that have investigated television viewing time on weekends in Brazil using a representative national sample with high response rates, factors that permit a more reliable analysis of the habits of Brazilian industry workers.

\section{Conclusions}

High television viewing time on weekends, regardless of weekday television viewing, was strongly associated with unhealthy eating habits. Furthermore, this behavior coexisted with physical activity in the leisure-time and household domains. These data permit to elaborate future practices applications, in which companies and the government are encouraged to promote intervention strategies focusing on actions that modify the weekend habits of workers. Further studies analyzing healthy behaviors in the workplace, including specific interventions to reduce the time spent watching television, should provide new opportunities to attenuate this relation.

\section{References}

1. Ekelund U, Brage S, Froberg K, Harro M, Anderssen SA, Sardinha LB et al. TV viewing and physical activity are independently associated with metabolic risk in children: the European Youth Heart Study. PLoS Med 2006; 3(12):e488.http://dx.doi.org/10.1371/journal.pmed.0030488.

2. Ford ES, Caspersen CJ. Sedentary behaviour and cardiovascular disease: a review of prospective studies. Int J Epidemiol 2012; 41(5):1338-53. http://dx.doi.org/10.1093/ije/dys078.

3. Proper KI, Singh AS, van Mechelen W, Chinapaw MJ. Sedentary behaviors and health outcomes among adults: a systematic review of prospective studies. Am J Prev Med 2011; 40(2):174-82. http:// dx.doi.org/10.1016/j.amepre.2010.10.015.

4. World Health Organization. Global status report on noncommunicable diseases 2014. http://apps.who.int/iris/bitstre am/10665/148114/1/9789241564854_eng.pdf?ua=1.2014. (last accessed 11 October, 2015).

5. Boeing H, Bechthold A, Bub A, Ellinger S, Haller D, Kroke A et al. Critical review: vegetables and fruit in the prevention of chronic diseases. Eur J Clin Nutr 2012; 51(6):637-63.

6. Lee IM, Shiroma EJ, Lobelo F, Puska P, Blair SN, Katzmarzyk $\mathrm{PT}$ et al. Effect of physical inactivity on major non-communicable diseases worldwide: an analysis of burden of disease and life expectancy. Lancet 2012; 380(9838):219-29.

7. Chau JY, der Ploeg HP, van Uffelen JG, Wong J, Riphagen I, Healy GN. Are workplace interventions to reduce sitting effective? A systematic review. Prev Med 2010; 51(5):352-56. http://dx.doi. org/10.1016/j.ypmed.2010.08.012.

8. Chaput JP, Klingenberg L, Astrup A, Sjodin AM. Modern sedentary activities promote overconsumption of food in our current obesogenic environment. Obes Rev 2011; 12(5):e12-20. http:// dx.doi.org/10.1111/j.1467-789X.2010.00772.x.

9. Pearson N, Biddle SJ. Sedentary behavior and dietary intake in children, adolescents, and adults: a systematic review. Am J Prev Med 2011; 41(2):178-88.
10. Rosiek A, Maciejewska NF, Leksowski K, Rosiek-Kryszewska A, Leksowski Ł. Effect of television on obesity and excess of weight and consequences of health. Int J Environ Res Public Health 2015; 12(8):9408-26.

11. Matthews CE, Chen KY, Freedson PS, Buchowski MS, Beech $\mathrm{BM}$, Pate RR,et al. Amount of time spent in sedentary behaviors in the United States, 2003-2004. Am J Epidemiol 2008; 167(7):87581. http://dx.doi.org/10.1093/aje/kwm390.

12. Christian TJ. Trade-offs between commuting time and health-related activities. J Urban Health 2012; 89(5):746-57.

13. Smith LP, Ng SW, Popkin BM. No time for the gym? Housework and other non-labor market time use patterns are associated with meeting physical activity recommendations among adults in fulltime, sedentary jobs. Soc Sci Med 2014; 120(1):126-34. http:// dx.doi.org/10.1016/j.socscimed.2014.09.010.

14. Brasil. (Ministério da Fazenda) Anuário Estatístico da Previdência Social/Ministério da Fazenda, Secretaria de Previdência, Empresa de Tecnologia e Informações da Previdência. Brasília; 2016.

15. Barros M, Nahas M. Comportamentos de risco, auto-avaliacao do nivel de saude e percepcao de estresse entre trabalhadores da industria. Rev Saude Publica; 2001;35(6):554-63.

16. Barros MVG. Atividades físicas no lazer e outros comportamentos relacionados à saúde dos trabalhadores da indústria no Barriers to physical activity in adults 7 estado de Santa Catarina, Brasil. Dissertation, Federal University of Santa Catarina, Santa Catarina. 1999.

17. Fonseca SA, Blank VLG, Barros MVG, Nahas MV. Percepção de saúde e fatores associados em industriários de Santa Catarina, Brasil. Cad Saúde Pública 2008; 24(1):567-76.

18. Dunstan DW, Barr EL, Healy GN, Salmon J, Balkau B, Magliano DJ. Television viewing time and mortality: the Australian Diabetes, Obesity and Lifestyle Study (AusDiab). Circulation 2010;121(3):38491. http://dx.doi.org/10.1161/circulationaha.109.894824.

19. Stamatakis E, Hamer M, Dunstan DW. Screen-based entertainment time, all-cause mortality, and cardiovascular events: population-based study with ongoing mortality and hospital events follow-up. J Am Coll Cardiol 2011; 57(3):292-99. http://dx.doi. org/10.1016/j.jacc.2010.05.065.

20. Brasil. (Ministério da Saúde) Guia Alimentar para População Brasileira promovendo a alimentação saudável. http://bvsms.saude. gov.br/bvs/publicacoes/guia_alimentar_populacao_brasileira_2ed. pdf.2014. (last accessed 20 September, 2015).

21. Chau JY, Grunseit AC, Chey T, Stamatakis E, Brown WJ, Mattheews CE. et al. Daily Sitting Time and All-Cause Mortality: A MetaAnalysis. PLoS ONE 2013; 8(11):e80000. http://dx.doi.org/10.1371/ journal.pone.0080000.

22. Owen N, Sugiyama T, Eakin EE, Gardiner PA, Tremblay MS, Sallis JF. Adults' sedentary behavior determinants and interventions. Am J Prev Med 2011; 41(2):189-96. http://dx.doi.org/10.1016/j. amepre.2011.05.013.

23. Hadgraft NT, Lynch BM, Clark BK, Healy GN, Owen N, Dunstan DW. Excessive sitting at work and at home: Correlates of occupational sitting and TV viewing time in working adults. BMC Public Health 2014; 15(1):899. http://dx.doi.org/10.1186/s12889-015-2243-y.

24. Banks E, Lim L, Seubsman SA, Bain C, Sleigh A. Relationship of obesity to physical activity, domestic activities, and sedentary behaviours: cross-sectional findings from a national cohort of over 
70,000 Thai adults. BMC Public Health 2011;11(1):762. http:// dx.doi.org/10.1186/1471-2458-11-762.

25. Owen N, Healy GN, Matthews CE, Dunstan DW. Too Much Sitting: The Population-Health Science of Sedentary Behavior. Exerc Sport Sci Ver 2010; 38(3):105-13. http://dx.doi.org/10.1097/ JES.0b013e3181e373a2.

26. Clemes SA, O'connell SE, Edwardson CL. Office workers' objectively measured sedentary behavior and physical activity during and outside working hours. Int J Occup Environ Med 2014; 5(3):298-03.

27. Mansoubi M, Pearson N, Biddle SJ, Clemes S. The relationship between sedentary behaviour and physical activity in adults: a systematic review. Prev Med 2014; 69(1):28-35. http://dx.doi. org/10.1016/j.ypmed.2014.08.028.

28. Healy GN, Matthews CE, Dunstan DW, Winkler EA, Owen N. Sedentary time and cardio-metabolic biomarkers in US adults: NHANES 2003-06. Eur Heart J 2011; 32(5):590-97. http://dx.doi. org/10.1093/eurheartj/ehq451.

29. Blass EM, Anderson DR, Kirkorian HL, Pempek TA, Price I, Koleini MF. On the road to obesity: Television viewing increases intake of high-density foods. Physiol Behav 2006; 88(4-5):597-04. http://dx.doi.org/10.1016/j.physbeh.2006.05.035.

30. Sanchez A, Norman GJ, Sallis JF, Calfas KJ, Rock C, Patrick K. Patterns and correlates of multiple risk behaviors in overweight women. Prev Med 2008; 46(3):196-02. http://dx.doi.org/10.1016/j. ypmed.2007.10.005.

31. Del Duca GF, Silva KS, Garcia LM, de Oliveira ES, Nahas MV. Clustering of unhealthy behaviors in a Brazilian population of industrial workers. Prev Med 2012; 54(3-4):254-58. http://dx.doi. org/10.1016/j.ypmed.2012.02.005.
32. Poortinga, W. The prevalence and clustering of four major lifestyle risk factors in an English adult population. Prev Med 2007; 44(2):124-28. http://dx.doi.org/10.1016/j.ypmed.2006.10.006.

33. Chou KL. The prevalence and clustering of four major lifestyle risk factors in Hong Kong Chinese older adults. J Aging Health 2008; 20(7),788-03. http://dx.doi.org/10.1177/0898264308321082.

34. Gantz W, Schwartz N, Angelini JR Television Food Advertising to Children in the United States. 2007.

\section{Corresponding author}

Marina Christofoletti

Federal University of Santa Catarina, Reitor João David Ferreira Lima Campus, Degree Coordenation of Physical Education. Zipe Code: 88040-900. Florianopolis, Santa Catarina, Brazil.

Email: marinachriss@outlook.com

Manuscript received on November 1, 2018

Manuscript accepted on April 16, 2019

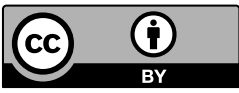

Motriz. The Journal of Physical Education. UNESP. Rio Claro, SP, Brazil - eISSN: 1980-6574 - under a license Creative Commons - Version 4.0 